\title{
DETEKSI FENOTIP Candida spp PADA PASIEN SUSPEK TUBERKULOSIS
}

\author{
Anita $^{1}$, Nur Qadri Rasyid ${ }^{1}$, Nurul Ni’ma Azis ${ }^{1}$ \\ ${ }^{1)}$ Akademi Analis Kesehatan Muhammadiyah, Makassar. \\ Alamat Korespondensi: nita_uh@yahoo.co.id
}

\begin{abstract}
Abstrak
Penyakit paru selain disebabkan oleh Mycobacterium tuberculosis juga ditemukan adanya peranan agen yang lain yaitu jamur Candida spp. Penelitian ini bertujuan untuk untuk mengidentifikasi Candida spp secara fenotip yang terbentuk pada medium Sabaroud Dekstrosa Agar dan mengukur kecepatan pertumbuhan dan keakuratan (sensitifitas dan spesifisitas) medium Sabaroud Dekstrosa Agar. Desain penelitian adalah observational studi dengan jumlah sampel 35 bilasan bronkus dari penderita suspek tuberkulosis sebanyak 33 orang. Analisis data cross tabulasi digunakan untuk mengukur sensitifitas dan spesifitas Sabaroud Dekstrosa Agar untuk mendeteksi Candida spp. Dari hasil penelitian dtemukan pertumbuhan jamur pada dari sputum BTA negatif pada medium Sabaroud Dektrosa Agar (SDA) $37^{\circ} \mathrm{C}$, jumlah sampel yang positif pertumbuhan Candida spp yaitu 17 (5.95\%), sedangkan yang negatip pertumbuhan Candida spp yaitu $15(5.25 \%)$ sampel, dan kontaminasi yaitu 3 (1.05\%), dengan rata-rata waktu pertumbuhan berkisar 1-2 hari. Dengan demikian dapat disimpulkan bahwa media Sabaroud Dekstrosa Agar sensitif dan spsesifik dalam mendeteksi secara fenotif jamur Candida spp pada pasien suspek tuberkulosis.
\end{abstract}

Kata Kunci: Bilasan bronkus, Candida spp, Sabaroud Dektrosa Agar, Tuberkolosis.

\section{PENDAHULUAN}

Penyakit infeksi masih tetap menjadi masalah utama kesehatan di Indonesia, salah satunya adalah penyakit tuberkulosis paru yang disebabkan oleh Mycobacterium tuberculosis (Sudoyo, 2007). Laporan WHO yang terbaru (2006), masih menempatkan Indonesia sebagai negara dengan pasien TB terbanyak ke-3 di dunia setelah India dan Cina. Diperkirakan jumlah pasien tuberkulosis di Indonesia sekitar 10\% dari total jumlah pasien tuberkulosis di dunia (Pedoman Nasional Penanggulangan Tuberkulosis, 2006).

Sekitar dua dekade terakhir invasi penyakit infeksi jamur terus mengalami peningkatan sebagai akibat penggunaan steroid dan antibiotik spektrum luas, terjadinya infeksi primer dan sekunder pada penderita tuberkolosis paru, terdapatnya faktor predisposisi yaitu penyakit kronik yang berat termasuk penyakit kegananasan atau penyakit kronik lainnya seperti diabetes melitus (Widyasari, et.al., 2012).

Gejala umum infeksi jamur paru sama dengan infeksi tuberkulosis atapun dengan mikroba lainnya, antara lain batuk-batuk, batuk darah, banyak dahak, sesak, demam, nyeri dada dan bisa juga tanpa gejala. Oleh karena infeksi jamur paru sering menyertai penyakit lain dan tidak ada gejala yang khas sehingga infeksi jamur paru sering tidak terdiagnosa, sehingga pengobatan terhadap infeksi jamur paru sering terlambat diberikan (Sukamto, 2004).

Spesies Candida merupakan infeksi jamur tersering penyebab kandidiasis pada manusia, dapat terjadi di seluruh dunia dan menyerang segala usia, baik laki-laki maupun wanita (Maharani S., 2012).

Permasalahan lain yang kemudian timbul ialah bahwa baik gambaran klinik maupun radiologik penderita infeksi jamur paru tidak khas (Sudoyo, 2007). Beberapa identifikasi kultur konvensional dan dilanjutkan dengan tes biokimia membutuhkan waktu yang lama, (Mandigan M.T., dkk, 2009). Oleh karena itu diperlukan metode fenotip yang mudah, sederhana dan murah untuk mengidentifikasi antara Candida spp. 


\section{METODE PENELITIAN}

\section{Alat dan Bahan}

Alat yang digunakan adalah autoklaf, Bio Safety Cabinat (ESCO class II Type A2), lampu Bunsen, inkubator, kaca objek, kotak kaca objek, lemari asam, mikroskop, neraca analitik, ose bulat, $\mathrm{pH}$ meter, platel well, rak tabung, sentrifugasi, stopwatch, tabung eppendorf, tabung falcon $50 \mathrm{~mL}$, vortex, pinset, gunting, waterbath, freezer, gelas kimia, Erlenmeyer, sendok timbangan dan stirrer magnetic.

Bahan yang digunakan adalah sampel cairan pleura, bilasan bronkus, kapas, alcohol, karbol fuchsin, metilen blue, medium Sabaroud Dextrose Agar, dan air steril.

\section{Prosedur Kerja \\ Pembuatan Sabouraud glukosa agar hipertonik}

Bahan medium Sabouraud dimasukkan ke dalam labu kimia steril kemudian dicampur. Medium kemudian diautoclave pada suhu $121^{\circ} \mathrm{C}$ selama 15 menit . Medium yang telah jadi dituangkan ke dalam botol McCartney steril sebanyak 6-8 $\mathrm{ml}$.

\section{Kultur Sabouraud Glukosa Agar Hipertonik}

Sampel diambil dengan menggunakan ose bulat kemudian diinokulasi pada medium Sabouraud Glukosa Agar Hipertonik 7x24 jam pada suhu $28{ }^{\circ} \mathrm{C}$. Koloni jamur pada media Sabouraud Glukosa Agar Hipertonik berwarna putih, agak mengkilat dan halus. Sel khamir yang diamati berbentuk bulat atau oval.

\section{Smear dengan pengecatan Gram}

Biakan Candida sp diambil menggunakan ose bulat diteteskan pada permukaan gelas benda dan dibuat preparat dengan ukutan $2 \times 3 \mathrm{~cm}$, kemudian difiksasi pada hotplate selama 2 menit. Selanjutnya dituangkan cristal violet dibiarkan 2 menit, cuci dengan air mengalir, lalu dituangkan lugol dibiarkan 38 detik, cuci dengan air mengalir. Lalu tuangkan alkohol $96 \%$ dibiarkan 10 detik, cuci dengan air mengalir. Kemudian tuangkan Fuchsin alkalis dibiarkan 40 detik, cuci dengan air mengalir.

\section{Analisis Data}

Data penelitian disajkan dalam bentuk dekskriptif dan untuk pengelolaan datanya digunakan SPSS 19 dengan analisis data cross tabulasi.

\section{HASIL DAN PEMBAHASAN}

Penelitian ini dilakukan di Laboratorium Tuberkulosis, Hasanuddin University Medical Research Centre Fakultas Kedokteran Universitas Hasanuddin Makassar. Total sampel dalam penelitian ini yaitu 35 bilasan bronkus dari penderita suspek Tuberkulosis sebanyak 33 orang di Infection Centre Rumah Sakit. Wahidin Sudirohusodo.

Sebelum melakukan proses kultur dengan medium Sabaroud Dektrosa Agar $37^{\circ} \mathrm{C}$ terlebih dahulu dilakukan pemeriksaan langsung secara mikroskopik terhadap sampel bilasan bronkus menggunakan metode smear dengan pewarnaan Ziehl-Neelsen. Pada hasil penelitian menunjukkan hasil pemeriksaan BTA dari 35 bilasan bronkus adalah negatif.

Tabel 1. Perbandingan tingkat isolasi Candida spp dari sampel bilasan bronkus

\begin{tabular}{ccccc}
\hline \multirow{2}{*}{ Media } & \multicolumn{4}{c}{ Hasil Kultur } \\
\cline { 2 - 5 } & Positif & $\begin{array}{c}\text { Negati } \\
\mathrm{f}\end{array}$ & $\begin{array}{c}\text { Konta } \\
\text { minasi }\end{array}$ & $\mathrm{N}$ \\
\hline SDA & 17 & 15 & 3 & \multirow{2}{*}{35} \\
$37^{\circ} \mathrm{C}$ & $(5.95 \%)$ & $(5.25 \%)$ & $(1.05 \%)$ & \\
\hline
\end{tabular}

Untuk sampel bilasan bronkus pada medium Sabaroud Dektrosa Agar (SDA) $37^{\circ} \mathrm{C}$, jumlah sampel yang positif pertumbuhan Candida spp yaitu 17 (5.95 $\%)$, sedangkan yang negatip pertumbuhan Candida spp yaitu 15 (5.25 $\%)$ sampel, dan kontaminasi yaitu 3 $(1.05 \%)$. 
$\begin{array}{ll}\text { Tabel 2. } & \text { Rata-rata ertumbuhan } \\ \text { Candida spp dari sampel } \\ \text { bilasan bronkus }\end{array}$

\begin{tabular}{ccc}
\hline Media & $\begin{array}{c}\text { Waktu } \\
\text { Pertumbuhan } \\
\text { (Hari) }\end{array}$ & $\begin{array}{c}\text { Rata-Rata } \\
\text { Waktu } \\
\text { Pertumbuhan } \\
\text { (Hari) }\end{array}$ \\
\hline SDA & $1-2$ & 1 \\
$37^{0} \mathrm{C}$ & 1 & \\
\hline
\end{tabular}

Untuk rata-rata hari pertumbuhan koloni untuk Candida spp pada medium Sabaroud Dektrosa Agar (SDA) $37^{\circ} \mathrm{C}$ yaitu 1 hari yang berkisar antara 1-2 hari.

Hasil dari kultur tersebut yang positip selanjutnya dikonfirmasi dengan pemeriksaan mikroskopik dengan menggunakan pewarnaan gram yang bertujuan untuk menegaskan kembali apakah koloni yang tumbuh tersebut benar adalah Candida spp.

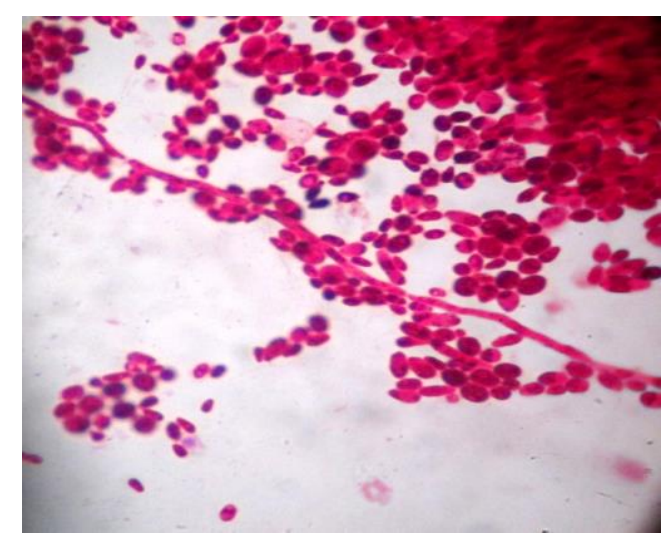

\section{Gambar 1. Hasil mikroskopik Candida} spp dengan perbesaran 100x

Sampel pada penelitian ini yaitu 35 bilasan bronkus dari penderita suspek Tuberkulosis sebanyak 33 orang. Selanjutnya dilakukan pemerikaaan mikroskopik yang memiliki peranan penting dalam diagnosis awal infeksi Mycobacterium karena metode pemeriksaan smear dapat menunjukkan hasil pemerikaaan yang cepat. Selain itu pemeriksaan secara mikroskopik dengan basil tahan asam (BTA) merupakan pemeriksaan yang sederhana, murah dan cukup sensitif untuk mendukung diagnosis penyakit tuberkulosis serta untuk menilai kemajuan pengobatan.

Setelah dilakukan pemeriksaan mikrokospik selanjutnya sampel diinokulasikan pada medium pertumbuhan yaitu SDA $37^{\circ} \mathrm{C}$ bertujuan untuk untuk mengetahui tingkat kemampuan baik sensitifitas maupun sensifitas medium SDA $37^{\circ} \mathrm{C}$ dalam mengisolasi jamur Candida spp. Koloni Candida spp yang tumbuh pada medium SDA $37^{\circ} \mathrm{C}$ akan tampak berwarna putih, halus, licin, ukuran koloni dari kecil sampai ukuran besar, jika koloni sudah berumur tua akan berwarna kecoklatan.

Dari data penelitian diperoleh bahwa medium SDA $37^{\circ} \mathrm{C}$ memilki tingkat pertumbuhan koloni yaitu jumlah sampel yang positif pertumbuhan Candida spp yaitu $17 \quad(5.95 \%)$, sedangkan yang negatip pertumbuhan Candida spp yaitu 15 (5.25\%) sampel, dan kontaminasi yaitu 3 (1.05\%). Kultur menjadi sangat penting untuk menghindari kesalahan dalam rutin identifikasi . Dari hasil penelitian diperoleh pula rata-rata hari pertumbuhan Candida spp antara mediumSDA $37^{\circ} \mathrm{C}$ yaitu 1 hari pasca inokulasi (Tabel 1).

Untuk rata-rata pertumbuhan jamur Candida spp pada medium Sabaroud Dekstrosa Agar yaitu 1 hari (Tabel 2.)

Setelah didapatkan hasil kultur yang positif dari medium SDA $37^{\circ} \mathrm{C}$ selanjutnya dilakukan uji konfirmasi dengan pemeriksaan mikroskopik kembali menggunakan pewarnaan gram. Uji konfirmasi ini dilakukan bertujuan untuk menegaskan kembali apakah koloni yang tumbuh pada media tersebut benar adalah Candida spp (Gambar 1).

Hasil pengamatan mikrokopik tersebut menunjukkan keberadaan Candida spp pada media, dimana koloni tersebut nampak adanya budding spora pada ujung blastopora. Selain itu nampak pula adanya hifa dimana spora jmaur melekat pada hifa tersebut (Gambar 1). Pemeriksaan mikroskopik yang memiliki peranan penting dalam diagnosis awal infeksi Mycobacterium karena metode pemeriksaan smear dapat menunjukkan hasil pemeriksaan yang cepat. Selain itu pemeriksaan secara mikroskopik dengan basil tahan asam (BTA) merupakan pemeriksaan yang sederhana, murah dan cukup sensitif untuk mendukung 
diagnosis penyakit tuberkulosis serta untuk menilai kemajuan pengobatan.

\section{KESIMPULAN}

Dari penelitian ini dapat disimpulkan bahwa untuk mendeteksi Candida spp dari bilasan bronkus pasien suspek tuberkulosis dapat menggunakan Sabaroud Glukosa Agar yang merupakan medium yang murah, sederhana dan dapat digunakan untuk rutin identifikasi Candida spp.

SARAN

Oleh karena itu kami menyarankan untuk dapat dilakukan penelitian lebih lanjut tentang identifikasi Candida spp dari berbagi sumber spesimen.

\section{DAFTAR PUSTAKA}

Ayman, A., Ihab, M. Salem. 2012. Evaluation of Rapid Molecular Identification of Clinically Important Candida Spp Isolated From Immunocompromised Patients Using RF-PCR. Journal of American Sciense, $8: 2$.

Chowdhry, et.al. 2010. Application of hypertonic Sabaroud glucose agar for differentiation of Candida dubliniensis from Candida albicans. Diagnostic Microbiology and Infectious Disease, 69:440442.

Ells R., 2009. Candida albicans or Candida dubliniensis. Mycoses Diagnosis, Therapy and Prophylaxis of Fungal Diseases 54: 1-16.

Liguori G., dkk. 2010. Candida albicans identification: comparison among nine phenotypic systems and $a$ multiplex PCR. J PREV MED HYG, 51:121-124.

Ligouri G dkk. 2010. Comparison between multiplex PCR and phenotypic systems for Candida spp identification. Medical Journal Indonesiaa, 33:63-67.

Maharani, S. 2012. Pengaruh Pemberain Larutan Ektrak Siwak (Salvadora persica) Pada Berbagai Konsentrasi Terhadap Pertumbuhan Candida albicans. Semarang.
Moran P, dkk. 2011. Candida albicans versus Candida dubliniensis :Why Is C. albicans More Pathogenic. International Journal of Microbiology.7 pages.

Sandra A., dkk. 2010. Identification of Candida spp by Phenotypic Test and PCR. Brazilian Journal of Microbiology .41: 286-294.

Sukamto. 2004. Pemeriksaan Jamur Bilasan Bronkus Pada Penderita Bekas Tuberkulosa Paru. Medan: USU digital library.

Tarini dkk. 2010. Development of multiplex-PCR assay for rapid detection of Candida spp. Medical Journal Indonesia . 19: 83-7.

Widyasari, K., dkk. 2012. Invitro susceptibility of Candida spp isolate from pulmonary tuberculosis suspected patients to antifungal agent in Jakarta. Journal of Medicine and Medical Sciences. Vol 3(3),pp 138-140. 